Dicle Tıp Dergisi / Dicle Med J (2018) 45 (3) : 255-264

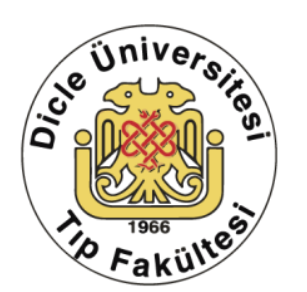

WWW.diclemedj.org

Özgün Araştırma / Original Article

\title{
Cinsiyet ve Yaş Farklılıklarının Ergenlerin Depresyon, Anksiyete Bozukluğu, Kendine Zarar Verme, Psikoz, Travma Sonrası Stres Bozukluğu, Alkol-Uyuşturucu Bağımlılığı ve Dikkat Eksikliği Hiperaktivite Bozukluğu İle İlişkili Sorunlara Etkisi
}

\author{
Selen Özakar Akça' ${ }^{1}$, Filiz Selen², Emre Demir ${ }^{3}$, Tahir Demir ${ }^{4}$ \\ 1 Hitit Üniversitesi Sağlık Bilimleri Fakültesi, Çorum, Türkiye ORCID: 0000-0002-6943-6713 \\ 2 Hitit Üniversitesi Sağllk Bilimleri Fakültesi, Çorum, Türkiye ORCID: 0000-0003-0913-9044 \\ 3 Hitit Üniversitesi, Tıp Fakültesi, Biyoistatistik Anabilim Dalı Çorum, Türkiye ORCID: 0000-0002-3834-3864 \\ 4 Çorum Milli Eğitim Müdürlüğü Rehberlik ve Araștırma Merkezi Çorum, Türkiye ORCID: 0000-0002-1748-1889
}

Geliş: 12.12.2017, Revizyon: 11.06.2018, Kabul Tarihi: 16.07.2018

Öz

Amaç: Bu çalışma ile ergenlerin cinsiyet ve yaşlarına göre depresyon, anksiyete bozukluğu, kendine zarar verme, psikoz, travma sonrası stres bozukluğu, alkol-uyuşturucu bağımlılığı ve dikkat eksikliği hiperaktivite bozukluğu ile ilişkili sorunlarının belirlenmesi amaçlanmıştır.

Yöntemler: Araștırma tanımlayıcı olarak, 2014-2015, 2015- 2016 öğretim yılında Milli Eğitim Müdürlüğ̈̈ne bağlı liselerdeki 15-18 yaş grubu öğrencilerde gerçekleștirilmiştir. Araştırma da toplam 917 ergen örnekleme alınmıştır. Veriler, Ergenleri Tanıtıcı Form, Ergenler İçin Ruhsal Sorunlar Tarama Ölçeği kullanılarak toplanmış ve uygun istatistiksel analizlerle değerlendirilmiştir.

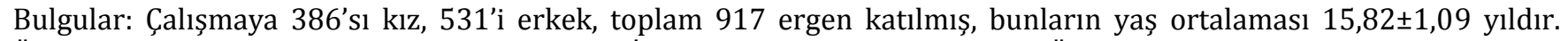
Örneklem grubundaki öğrencilerin Ergenler İçin Ruhsal Sorunlar Tarama Ölçeği ortalamasına göre; \%77,1'inin depresyon, \%75,0'inin anksiyete bozukluğu, \%65,3'ünün psikoz, \%96,5'inin dikkat eksikliği hiperaktivite bozukluğu ile ilişkili sorunlarının olabileceği belirlenmiștir. Öğrencilerin Ergenler İçin Ruhsal Sorunlar Tarama Ölçeği ortalamalarına göre; depresyon, anksiyete bozukluğu, kendine zarar verme, psikoz, travma sonrası stres bozukluğu, alkol-uyuşturucu bağımlılığı ve dikkat eksikliği hiperaktivite bozukluğu ile ilişkili sorunlarının cinsiyete göre dağılımına ilişkin sonuçlar incelendiğinde; örneklem grubundaki kız öğrencilerin erkek öğrencilere göre depresyon ve anksiyete bozukluğu ile ilişkili sorunlarının, erkek öğrencilerin de kız öğrencilere göre psikoz, alkol bağımlılığı ve dikkat eksikliği hiperaktivite bozukluğu ile iliş̧kili sorunlarının yüksek olduğu belirlendi.

Sonuç: Ergenlerin ilk üç sırada dikkat eksikliği hiperaktivite bozukluğu, depresyon ve anksiyete bozukluğu ile ilişkili sorunlarının yüksek olduğu düşünülürse; çocuk ergen ruh sağlığı alanında ulusal politikalar oluşturmanın temel bileşenlerinden birisi bu yaş grubunda ruhsal bozuklukların belirlenmesidir.

Anahtar Kelimeler: Ergen, dikkat eksikliği hiperkaktivite bozukluğu, depresyon, anksiyete bozukluğu.

DOI: $10.5798 /$ dicletip.457235

Yazışma Adresi / Correspondence: Selen Özakar Akça, Hitit Üniversitesi Sağlık Bilimleri Fakültesi, Çorum, Türkiye e-mail: selenozakar@hotmail.com 


\title{
Effect of Gender and Age Differences on Depression of Adolescents, Anxiety Disorder, Self-Injury, Psychosis, Post-Traumatic Stress Disorder, Alcohol-Drug Addiction and Attention Deficit Hyperactivity Disorder
}

\begin{abstract}
Objective: This study aims to determine the problems of adolescents related to depression, anxiety disorder, selfinjury, psychosis, post-traumatic stress disorder, alcohol-drug addiction and attention deficit hyperactivity disorder according to gender and age.

Methods: As a descriptive study, it was carried out in 2014-2015 and 2015-2016 academic years among 15-18 yearold group of high school students affiliated to the Directorate of National Education. A total of 917 adults constituted the sample of the research. The data were collected using the Descriptive Form for Adolescents and the Psychological Questionnaire Scale for the Adolescents and evaluated with appropriate statistical analyzes.

Results: A total of 917 adolescents, 386 girls and 531 men, participated in the study, and their average age is $15.82 \pm 1.09$. According to the average of the students in the sample group of Psychological Questionnaire Scale for the Adolescents; $77.1 \%$ of them had depression, $75.0 \%$ had anxiety disorder, $65.3 \%$ had psychosis, and $96.5 \%$ had Psychological Questionnaire Scale for the Adolescents related problems. According to the students' average of Psychological Questionnaire Scale for the Adolescents, when the results of gender distribution of problems related to depression, anxiety disorder, self-harm, psychosis, post-traumatic stress disorder, alcohol-drug addiction and attention deficit hyperactivity disorder were compared, female students' problems with depression and anxiety disorder were found to be higher while male students' problems with psychosis, alcohol addiction and attention deficit hyperactivity disorder were found to be higher.

Conclusion: Considering that the adolescents have a high incidence of attention deficit hyperactivity disorder, depression and anxiety disorders respectively, one of the key components of the national policies in the field of juvenile mental health is the identification of mental disorders in this age group.
\end{abstract}

Keywords: Adolescent, attention deficit hyperactivity disorder, depression, anxiety.

\section{GİRIS}

Ergenlik dönemi, çocukluk ile erişkinlik arasında yer alan, başlangıç ve bitiş zamanları kesin sinırlarla belirli olmayan ve genellikle 1019 yaşları arasında olan bir süreçtir. $\mathrm{Bu}$ dönemin biyolojik, psikolojik ve sosyal yönden önemli gelişme, ruhsal olgunlaşma ve yaşama hazırlık evreleri bulunmakta ve hızlı bir dönem olarak devam etmektedir ${ }^{1,2}$.

Ergenlik döneminde hızlı yaşanan bedenle ilgili gelişmenin direk ya da dolaylı olarak ortaya çıkardığı psikolojik farklılaşmalar sonucunda ergen; uyumsuz, dengesiz, tedirgin ve kaygil olabilmektedir. Kararsızlık ve bocalama içinde olan ergenin duyguları, bağlllıkları değişebilmekte, heyecanları sınırsız, dengesiz ve ölçüsüz şekildeki farklılıklarla kendini gösterebilmektedir. Bu dönemdeki farklılıkların neden olduğu gergin ruh durumu, ergenin yalnızlı duygusu yaşaması, depresif bozuklukların gelişmesi gibi farklı ruhsal sorunların ortaya çıkmasının nedenleri arasindadir ${ }^{3,4}$.

Ergenlerde ruhsal sorun yaygınlığının araştırıldığı çalışmalarda yaygınlık oranı \%1321 olarak belirtilmekte, ergenlerin en az bir kez 16 yaşına gelene kadar ruhsal bozukluk geçirdiği ve bu oranın kızlarda \%31, erkeklerde $\% 42$ olduğu bildirilmektedir ${ }^{4}$. Çocuklukta başlayan ruhsal bozukluklar erkeklerde, ergenlikte başlayan ruhsal bozuklukların da kızlarda daha fazla görüldüğü belirtilmiştir ${ }^{5}$. Klinisyenlerin karşılaştıkları çocukların \%4050'sinde davranışsal, psikososyal ve eğitimle ilgili sorunlar yer almakta, ergenlerin yaklașık \%10-25'inde ciddi ruhsal bozukluklar sergilenmekte ve erişkin dönemindeki ruhsal bozuklukların bu dönemde başladığı bildirilmektedir ${ }^{6,7}$. 
Ergenlerin karşılaştığı ruhsal sorunlar kişiler arası ilişkilerden birçok nevrotik eğilimlere, riskli sağlık davranışlarına hatta intihar boyutuna kadar değişim gösterebilmektedir ${ }^{5}$. $\mathrm{Bu}$ yaşlarda görülebilecek ruhsal bozukluklar normal ruhsal gelişimi etkileyerek ergenlerin işlevselliklerine erişmesini engelleyebilir. $\mathrm{Bu}$ bozuklukların belirlenmesi, önlenmesi ve tedavisi, bu yaş grubundaki varolan problemlerin giderilmesi kadar erişkin yaşamındaki işlevselliğin artırılması ve problemlerin gelecekte tekrarlanmasının önlenmesi açısından da önemini ortaya koymaktadır7. Ayrıca ergenlerin yaşamış oldukları ruhsal sorunların ortaya konulması, ruhsal sorunları önlemeye yönelik stratejilerin değerlendirilmesi ve yeni stratejilerin geliştirilmesine yardımcl olacağ düşünülmektedir.

15-18 yaş grubunun ergen olduğu göz önüne alınırsa; bu yaş grubunda yapılan ulusal ve uluslararası çalışmaların yetersiz olduğu belirlenmiş, konu ile ilgili çalışmalar zayıf kalmıştır. Bu doğrultuda bu çalışma ile; cinsiyet ve yaş farklılıklarının ergenlerin depresyon, anksiyete bozukluğu, kendine zarar verme, psikoz, travma sonrası stres bozukluğu, alkoluyuşturucu bağımlılığı ve dikkat eksikliği hiperaktivite bozukluğu (DEHB) ile ilişkili sorunlarına etkisinin belirlenmesi ve ailesinin bilgilendirilerek yönlendirilmesi amaçlanmıştır.

\section{YÖNTEMLER}

Araştırma, lise düzeyinde öğrenim gören öğrencilerin depresyon, anksiyete bozukluğu, kendine zarar verme, psikoz, travma sonrası stres bozukluğu, alkol-uyuşturucu bağımlılığı ve DEHB ile ilişkili sorunlarının cinsiyet ve yaş farklılıklarına göre belirlenmesi amacıyla tanımlayıcı olarak gerçekleştirilmesi planlanmıştır. Helsinki Deklerasyonu kurallarına uygun olarak yapılan bu araştırmaya başlamadan önce Etik Kurul onayı (E-15-438) ve kurum izni (1756257/17.02.2015) alınmıştır. Araştırmaya gönüllü olarak katılan bütün öğrencilere araştırma ile ilgili açıklama yapılmış ve yazılı onam alınmıştır. Ayrıca Ergenler İçin Ruhsal Sorunlar Tarama Ölçeği'ni geliştiren yazardan ölçeğin veri toplamada kullanılabilmesi için eposta yolu ile izin alınmıştır.

Araştırmanın bağımsız değişkenlerini ergenlerin cinsiyeti ve yaşı; bağımlı değişkenini ise Ergenler İçin Ruhsal Sorunlar Tarama Ölçeği'nden aldıkları değerler oluşturmuştur.

Araştırmanın evrenini Milli Eğitim Müdürlügü'ne bağlı olan 2014-2015, 20152016 öğretim yılında resmi (76 okul=28682 öğrenci) ve özel (10 okul=998 öğrenci) lise kurumlarında öğrenim gören İl merkezinde bulunan toplam 86 okulun öğrencileri oluşturmuştur. Araştırmanın örneklemi belirlenirken sonlu bir popülasyon için ana kütle hacmi bilindiğinden $n=\left(N^{*} t^{\wedge} 2^{*} p^{*} q\right) /\left(d^{\wedge} 2\right.$ $\left.(\mathrm{N}-1)+\mathrm{t}^{\wedge} 2^{*} \mathrm{p}^{*} \mathrm{q}\right)$ formülü kullanılmıștır. Formülde; N: Hedef kitledeki birey sayısı, n: Örnekleme alınacak birey sayısı, p: İncelenen olayın görülüş sıklığı (gerçekleşme olasılığı), q: İncelenen olayın görülmeyiş sıklığl (gerçekleşmeme olasılığı, 1-p), t: Belirli bir anlamlılık düzeyinde, $\mathrm{t}$ tablosuna göre bulunan teorik değer, d: Olayın görülüş sıklığına göre kabul edilen \pm örnekleme hatasıdır. $\mathrm{N}=29680$, $p=0,5 q=0,5 \mathrm{t}=2,58 \mathrm{~d}=0,05$, veriler formülde yerine koyulduğunda örneklem hacmi için alınabilecek minimum sayı $n=651$ olarak belirlenmiştir. Hesaplanan örneklem sayısının değişkenler arasındaki bağın ortaya konulmasında daha güçlü olması amacıyla toplam 917 öğrencinin örneklemi oluşturmasına karar verilmiştir. Örneklem seçilirken okulların her biri birer tabaka olarak belirlenmiş ve 86 okulun tamamından sınıf düzeyleri dikkate alınmadan basit rastgele örnekleme yöntemi ile öğrenciler çalışmaya dahil edilmiştir.

Örneklem seçiminde kriterler; lise öğrencisi olması, iletişimi engelleyecek bir sorunu olmaması, ve çalışmaya katılmaya istekli, gönüllü olması ve çocuğun ailesinin onay vermiş olmasıdır. 
Veri toplama aracı olarak; Ergenleri Tanitıcı Form (ETF), Ergenler İçin Ruhsal Sorunlar Tarama Ölçeği (ERSTÖ) kullanılmıştır.

Ergenleri Tanıtıcı Form (ETF), ergenlerin cinsiyetini ve yaşını belirlemeye yönelik sorulardan oluşmaktadır.

Ergenler İçin Ruhsal Sorunlar Tarama Ölçeği (ERSTÖ), geliştirilirken, tutuklu ve hükümlü ergenlerin risk ve ihtiyaçlarının belirlenerek uygun girişimlerin oluşturulabilmesi için yapılan "Yasalarla İhtilafa Düşen Çocuk ve Ergenler için Araştırma ve Değerlendirme Formu soruları kullanılmıştır ${ }^{8}$. Toplam 27 sorudan oluşan ölçek, depresyon, anksiyete, kendine zarar verme, psikoz, travma sonrası stres bozukluğu, alkol ve uyușturucu bağımlılığı, DEHB'yi belirleyen alt ölçekleri içermektedir. İki seçenekten oluşan soruların yanıtları "evet" ve "hayır"dır. DEHB inceleyen 5 soruda ise, "kısmen" seçeneğini de içeren 3 seçenek yer almaktadır. Ölçekten alınabilecek toplam en yüksek puan 32'dir. Yarı yapılandırılmış olan bu ölçek yüz yüze görüşme yöntemiyle kullanılabilecek şekilde planlanmıştır. Ölçekten alınan toplam puan Pearson korelasyon analizi ile karşılaştırıldığında, görüşmeciler arası güvenilirlik $r=0,89$ olarak bulunmuştur. ERSTÖ’nin iç tutarlılık analizinde, tüm ölçeğin Cronbach alfa güvenilirlik katsayısı 0,79, herhangi bir madde ölçekten çıkarıldığında, iç tutarlılık katsayısı 0,77 ile 0,81 arasında değişmektedir. Ölçeğin ölçüt bağıntılı geçerliliğini değerlendirmek amacıyla, ERSTÖ'nden alınan toplam puanlar ile Youth Self Report toplam puanları karşılaştırılmış, Pearson korelasyon analizinde iki ölçekten elde edilen toplam puanlar arasında pozitif korelasyon olduğu belirlenmiștir $(r=0,60)$.

ERSTÖ’nün bir tarama ölçeği olduğu fakat, bir tanı ölçeği olmadığı, tüm tarama ölçeklerinde olduğu gibi, müdahale edilmesi gereken risk ve gereksinimleri ortaya koyarak bir uyarı amacı taşıdığı bildirilmektedir ${ }^{9}$. $\mathrm{Bu}$ ölçeğin bu çalışmada kullanılmasının tercih edilme nedeni; ölçeğin daha ileri görüşme yöntemleriyle tanının konulabilmesi için bir yol gösterici olması, uygulama süresinin kısalığı ve daha geniş kapsamlı analiz etme veya müdahale gerektiren ergenlerin başarılı bir şekilde tanılanmasını sağladığının bildirilmesidir.

İstatistiksel analizler SPSS (Version 22.0, SPSS Inc., Chicago, IL, USA) paket programı ile yapılmıştır. Sayısal değişkenler Ortalama \pm Standart sapma olarak, kategorik değişkenler sayı ve yüzde olarak sunulmuştur. Öğrencilerin depresyon, anksiyete bozukluğu, kendine zarar verme, psikoz, travma sonrası stres bozukluğu, alkol-uyuşturucu bağımlılığı ve DEHB ile ilişkili sorunların cinsiyet ve yaş gruplarına göre ilişkisi ki-kare testi ile araştırılmıştır. İstatistiksel anlamlı farklılık $\mathrm{p}<0,05$ olarak değerlendirilmiştir.

\section{BULGULAR}

Çalışmaya katılan toplam 917 öğrencinin 386'sını kızlar, 531'ini erkekler oluşturmuş olup, yaş ortalaması 15,82 $\pm 1,09$ yıldır. Örneklem grubundaki öğrencilerin ERSTÖ ortalamasina göre; \%77,1'inin depresyon, \%75,0'inin anksiyete bozukluğu, \%65,3'ünün psikoz, \%96,5'inin DEHB ile ilişkili sorunlarının olabileceği belirlenmiștir (Tablo1).

Öğrencilerin cinsiyetlerine göre depresyon, anksiyete bozukluğu, psikoz, alkol kullanımı ve DEHB ile ilişkili sorunlar arasında istatistiksel olarak anlamlı bir ilişki olduğu belirlenmiștir $(p<0,05)$. Tablo 2'de öğrencilerin ERSTÖ ortalamalarına göre; depresyon, anksiyete bozukluğu, kendine zarar verme, psikoz, travma sonrası stres bozukluğu, alkoluyuşturucu bağımlılığı ve DEHB ile ilişkili sorunların cinsiyete göre dağılımına ilişkin sonuçlar incelendiğinde; örneklem grubundaki kız öğrencilerin erkek öğrencilere göre depresyon ve anksiyete bozukluğu ile ilişkili sorunlarının, erkek öğrencilerin de kız öğrencilere göre psikoz, alkol bağımlılığı ve DEHB ile ilişkili sorunlarının yüksek olduğu belirlenmiştir. 
Tablo 1: Öğrencilerin depresyon, anksiyete bozukluğu, kendine zarar verme, psikoz, travma sonrası stres bozukluğu, alkoluyuşturucu bağımlılığı ve dikkat eksikliği hiperaktivite bozukluğu ile ilişkili sorunlarının dağılımı (N=917)

\begin{tabular}{|c|c|c|c|c|}
\hline \multirow{3}{*}{ Ruhsal Sorunlar } & \multicolumn{4}{|c|}{ Sonuçlar } \\
\hline & \multicolumn{2}{|c|}{ Var } & \multicolumn{2}{|c|}{ Yok } \\
\hline & $\mathrm{n}$ & $\%$ & $\mathrm{n}$ & $\%$ \\
\hline Depresyon & 707 & 77,1 & 210 & 22,9 \\
\hline Anksiyete bozukluğu & 688 & 75,0 & 229 & 25,0 \\
\hline Kendine zarar verme & 288 & 31,4 & 629 & 68,6 \\
\hline Psikoz & 599 & 65,3 & 318 & 34,7 \\
\hline Travma sonrası stres bozukluğu & 309 & 33,7 & 608 & 66,3 \\
\hline Alkol bağımlılığı & 124 & 13,5 & 793 & 86,5 \\
\hline Uyuş̧turucu bağımlılığı & 62 & 6,8 & 855 & 93,2 \\
\hline Dikkat eksikliği hiperaktivite bozukluğu & 885 & 96,5 & 32 & 3,5 \\
\hline
\end{tabular}

Öğrencilerin depresyon, anksiyete bozukluğu, kendine zarar verme, psikoz, travma sonrası stres bozukluğu, alkol ve uyuşturucu bağımlılığı ve DEHB ile ilişkili sorunların yaşa göre dağılımı incelendiğinde; örneklem içerisindeki öğrencilerin yaşlarına göre depresyon, anksiyete bozukluğu, kendine zarar verme, travma sonrası stres bozukluğu, alkoluyuşturucu bağımlılığı ve DEHB ile ilişkili sorunlar arasında istatistiksel olarak anlamlı bir ilişki olduğu $(\mathrm{p}<0,05$; Tablo 3$)$ görülmüştür. $\mathrm{Bu}$ fark 18 yaşındaki öğrencilerin depresyon $(\% 92,2)$, anksiyete $(84,3)$ ve travma sonrası stres bozukluğu $(\% 48,0)$, alkol bağımlılığı $(26,5)$ ile ilişkili sorunlarının 15,16 ve 17 yaşındakilere göre yüksek olmasından, 16 yaşındakilerde kendine zarar verme $(\% 38,5)$ ve uyuşturucu bağımlılığı $(\% 13,5)$ ile ilişkili sorunların, 15, 17 ve 18 yaşındakilere göre yüksek olmasından, ayrıca DEHB ile ilişkili sorunların 15,16 ve 18 yaşındakilerde 17 yaşındakilere göre düşük olmasından kaynaklanmaktadır.

\section{TARTIŞMA}

Ergenlerde ruhsal sağlık; psikolojik sağlığın ve işlevinin ideal olması ve bunu devam ettirebilme yeteneği olarak tanımlanmaktadır. $\mathrm{Bu}$ dönemde görülebilecek psikolojik rahatsızlıklar normal ruhsal ilerlemeyi etkileyerek ergenlerin normal işlevselliklerine ulaşmasını engelleyebilir ${ }^{7}$. Ergenlik döneminde psikiyatrik bozuklukların prevalansının artmasına rağmen birçoğunun gerekli ruhsal yardımı almadığı yapılan epidemiyolojik çalışmalarda bildirilmiştir ${ }^{10}$. Bu doğrultuda 1518 yaş grubu ergen olan öğrencilerde depresyon, anksiyete bozukluğu, kendine zarar verme, psikoz, travma sonrası stres bozukluğu, alkol-uyuşturucu bağımlılığı ve DEHB ile ilişkili sorunların araştırıldığı çalışmamız, planlı olarak risk altında olanları değerlendirme ve risk yönetimi çalışmalarının gerekliliğini ortaya koymaktadır.

Günümüzde ruhsal sorunlar, yaygınlıkları ve kronikleşme eğilimleri nedeniyle halk sağlığ sorunu olarak ele alınmakta, son yıllarda ergenlerde ruhsal sorun gelişme riskinin giderek arttığı bilimsel çalışmalarda bildirilmektedir5,11. Lindemann ve ark. yaptıkları çalışmada DEHB'nin ergenler arasında en sık görülen nörodavranışsal bozukluk olduğunu belirtmiştir ${ }^{11}$. Sunulan çalışmada da örneklem içerisinde yer alan öğrencilerde \%96,5 oranı ile DEHB ile ilișkili sorunlar açısından en yüksek olduğu belirlenmiștir (Tablo 1). DEHB ile ilișkili sorunları, \%77,1 ile depresyon, \%75 ile de 
anksiyete bozukluğu ile ilișkili sorunlar izlemiştir. Çalışmamızda örneklem grubundaki öğrencilerde depresyon, anksiyete bozukluğu ve psikoz ile ilişkili sorunların yüksek olabileceği göz önüne alınırsa, madde kötüye kullanımı, panik bozukluk, sosyal fobi, yeme bozuklukları ve majör depresyonun başlangıcının ergenlik döneminde olduğu düşünülürse; çalışmamız 15-18 yaş grubu ergenlerde depresyon, anksiyete bozukluğu, kendine zarar verme, psikoz, travma sonrası stres bozukluğu, alkol-uyuşturucu bağımlılığı ve DEHB ile ilişkili sorunların tarama programlarıyla takip edilmesinin ve tedavisinin desteklenmesinin önemini ortaya koymaktadır.

Ergenlik döneminin en önemli özelliği olan hızlı büyüme ve farklılaşmalar konusunda bir düşünce birliği bulunmakta, bu değişme ve büyüme, cinsiyetler hatta bireyler arasında büyük farklar göstermektedir ${ }^{12}$. Durukan ve ark. tarafından yapılan çalışmada çocuk ve ergen hastalarda tanı dağılımını incelemişler, buna göre depresyon ve anksiyete belirtilerinin kızların erkeklerden daha çok gösterdikleri vurgulanmıştır ${ }^{13}$. Çalışmamızda literatürle uyumlu olarak örneklem grubundaki kız öğrencilerde \%82,5 oranı ile depresyon ve $\% 80,4$ oranı ile anksiyete ile ilişkili sorunların erkek öğrencilerinkinden (sırasıyla; \%69,7, \%67,6) yüksek olduğu belirlenmiş olup, istatistiksel olarak aralarındaki ilişkinin anlamlılığı görülmüştür ( $\mathrm{p}<0,001$; Tablo2). $\mathrm{Bu}$ bulgu kızların biyolojik ve kişilik yapısı, ruhsal özellikleri, sorunlarla başa çıkma biçimi, toplumsal ve kültürel konumu gereği depresyon ve anksiyeteye yatkınlığını artırması sonucu olabileceğini göstermektedir.

Kendine zarar verme davranışı, bilinçli bir ölüm isteği olmadan, isteyerek ve hedefli bir şekilde, hafif veya orta seviyede fiziksel zarar beklentisi ile yapılan ve doku hasarı ile sonuçlanan, tekrarlayıcı bir şekilde kişinin kendi bedenine yönelik müdahalesi olarak tanımlanmakta, genel olarak ortama tahammül edememenin ve uyumsuzluğun yarattığı baskıya cevap niteliğinde geliştiği belirtilmektedir ${ }^{14}$. Kendine zarar verme davranışının daha çok kızlarda görüldüğünü ve cinsiyet farklılıkları arasında istatistiksel anlamlılığın varlığını bildiren çalışmalar olduğu gibi14,15, cinsiyet farklılıklarına ilişkin bir tutarlılık olmadığını bildiren çalışmalarda ${ }^{16}$ yer almaktadır. Sunulan çalışmada da istatistiksel olarak kendine zarar verme davranışı ile ilişkili sorunlar açısından cinsiyet arasında anlamlı bir ilişki olmadığı görülmüştür ( $p>0,05$; Tablo 2).

Psikotik bozukluk gelişme riski ile ilgili yapılan yaygınlık araştırmalarında, cinsiyetler arasında fark belirlenmese de ${ }^{17}$, Binbay, Ulaş ve Elbi, erkeklerin psikotik bozukluk gelişme riskinin erkeklerde açıkça daha yüksek olduğunu işaret etmektedir ${ }^{18}$. Sunulan çalışmada da örneklem grubundaki erkeklerde kızlara göre psikoz ile ilişkili sorunların görülme oranının yüksek olduğu saptanmış olup, bu ilişkinin istatistiksel olarak anlamlı olduğu görülmüştür $(p<0,001$; Tablo2). $\mathrm{Bu}$ bulgu erkek öğrencilerde psikososyal etkenler sonrasında baş etme düzeneklerinin yeterli gelişmemiş olmasından ve yetersiz ego gelişiminden kaynaklı olabileceğini düşündürmektedir.

Amerikan Psikiyatri Birliği travma sonrası stres bozukluğunu, kişinin aşırı bir travmatik stresörle karşılaşmasından, yaşamasından veya duymasından sonra, olayların kişiye sıkıntı veren bir biçimde yeniden yaşanması, kaçınma örüntüsü, duygulanımda küntlük ile birlikte otonomik, disforik ve bilișsel bulguların değişik derecelerde bulunması ile belirli bir ruhsal bozukluk olarak tanımlamaktadır ${ }^{19}$. Yapılan çalışmalarda cinsiyetin travma sonrası stres bozukluğunda savunma ve başa çıkma tarzını, sosyal desteği etkilediği bildirilmiştir. Binbay, Direk ve Aker tarafından yapılan çalışmada travma sonrası stres bozukluğunun kızlarda daha çok ortaya çıktığı bildirilmekte 20,21 , özellikle cinsel saldırıların bunun nedeni olduğu belirtilmektedir ${ }^{21}$. Sunulan çalışmada ise örneklemdeki173 erkek, $136 \mathrm{klz}$ ergenin travma sonrası stres bozukluğu ile ilişkili 
sorunlarının olabileceği, cinsiyetler arasında istatistiksel olarak anlamlı ilişki bulunmadığı görülmüștür ( $p>0,05$; Tablo 2). Travma sonrası ortaya çıkan bozukluklar erken dönemde tanınmaz ve müdahale edilmezse kronikleşip birey ve toplum için maliyeti yüksek olan ciddi bir sağllk sorunu haline gelebileceğinden, bu bulgu ergenlerin ruhsal sorun taramalarının belirli aralıklarla yapılması ve değerlendirilmesinin önemini ortaya koymaktadır.

Tablo 2: Öğrencilerin depresyon, anksiyete bozukluğu, kendine zarar verme, psikoz, travma sonrası stres bozukluğu, alkoluyuşturucu bağımlılığı ve dikkat eksikliği hiperaktivite bozukluğu ile ilişkili sorunlarının cinsiyete göre dağılımı

\begin{tabular}{|c|c|c|c|c|c|}
\hline \multirow{3}{*}{ Ruhsal Sorunlar } & \multicolumn{4}{|c|}{ Cinsiyet } & \multirow{3}{*}{$\mathbf{p}$} \\
\hline & \multicolumn{2}{|c|}{$\begin{array}{c}\mathbf{K 1 z} \\
\mathrm{n}=386(\% 42,1)\end{array}$} & \multicolumn{2}{|c|}{$\begin{array}{c}\text { Erkek } \\
\mathrm{n}=531(\% 57,9)\end{array}$} & \\
\hline & Evet & Hayır & Evet & Hayır & \\
\hline Depresyon & $438(\% 82,5)$ & $93(\% 17,5)$ & $269(\% 69,7)$ & $117(\% 30,3)$ & $<0,001^{* *}$ \\
\hline Anksiyete bozukluğu & $427(\% 80,4)$ & $104(\% 19,6)$ & $261(\% 67,6)$ & $125(\% 32,4)$ & $<0,001^{* *}$ \\
\hline Kendine zarar verme & $128(\% 33,2)$ & $258(\% 66,8)$ & $160(\% 30,1)$ & $371(\% 69,9)$ & 0,329 \\
\hline Psikoz & $224(\% 58,0)$ & $162(\% 42,0)$ & $375(\% 70,6)$ & $156(\% 29,4)$ & $<0,001^{* *}$ \\
\hline Travma sonrası stres bozukluğu & $136(\% 35,2)$ & $250(\% 64,8)$ & $173(\% 32,6)$ & $358(\% 67,4)$ & 0,401 \\
\hline Alkol bağımlılığı & $47(\% 8,9)$ & $484(\% 91,1)$ & $77(\% 19,9)$ & $309(\% 80,1)$ & $<0,001^{* *}$ \\
\hline Uyuşturucu bağımlılığı & $29(\% 5,5)$ & $502(\% 94,5)$ & $33(\% 8,5)$ & $353(\% 91,5)$ & 0,066 \\
\hline $\begin{array}{l}\text { Dikkat eksikliği hiperaktivite } \\
\text { bozukluğu }\end{array}$ & $366(\% 94,8)$ & $20(\% 5,2)$ & $519(\% 97,7)$ & $12(\% 2,3)$ & $0,017^{*}$ \\
\hline
\end{tabular}

Not: Ki-kare testi, ${ }^{*} \mathrm{p}<0,05, * * \mathrm{p}<0,01$

Ergenler bağımlılık yapıcı maddeyi olumsuz duyguları ile baş edebilmek ve hoşa giden duygular yaşayabilmek için kullanmakta, ayrıca ergenler için bu maddeleri kullanma, büyümenin bir göstergesi olarak değerlendirilmektedir ${ }^{22,23}$. Günümüzde alkol ve madde bağımlılı̆̆ı sorunu tüm dünyada olduğu gibi ülkemizde de birey ve toplumu tehdit etmekte, giderek ciddi bir artış ve yaygınlaşma göstermekte ${ }^{23}$, ayrıca bu maddeleri kullanmaya başlama yaşının da küçüldüğü bildirilmektedir ${ }^{22}$. Kastamonu ilinde madde kullanımı ve ilişkili faktörlerin incelendiği 950 lise öğrencisiyle yapılan araştırma kapsamında madde kullanan erkeklerin oranının kızlara göre yüksek olduğu belirlenmiștir ${ }^{24}$. Sunulan çalışmada örneklemdeki erkek öğrencilerde alkol-uyuşturucu bağımlılığı ile ilişkili sorunların kız öğrencilere göre daha yüksek olduğu belirlenmiş ve cinsiyete göre alkol bağımlığı ile ilişkili sorunlar arasında istatistiksel olarak anlamlllı belirlenirken $(p<0,001)$, uyuşturucu bağımlılığı ile ilişkili sorunlar arasında istatistiksel olarak anlamlılık saptanmamıştır ( $p>0,05$; Tablo 2). Bağımlılık yapıcı maddelerin kullanılması bireylerin fiziksel ve ruhsal sağlığını negatif yönde etkilemekte ve bu madde kullanımının devamlılığı sonucu yaşamin ilerleyen dönemlerinde etkilerinin giderek arttığı görülmektedir ${ }^{25}$. Bu maddelerin kullanımının ergenlik döneminde başladığ $1^{22,25}$ göz önüne alınırsa; bu bulgu, kız ve erkek öğrencilerde alkol-uyuşturucu bağımlılığı ile ilişkili sorunların azımsanmayacak derecede yüksek olduğunu göstermekte ve ergenlere önleyici çalışmaların gereksinimini ortaya koymaktadır.

Dikkatsizlik, aşırı hareketlilik, dürtüsellik, akademik başarısızlık ve sosyal problemlerle karakterize olan DEHB'nin, pratikte karşılașllan 
davranış sorunlarının \%10'unu oluşturduğu ve erkeklerde daha sık görüldüğü belirtilmiştir ${ }^{5}$. Ergenlerde DEHB sıklığının araştırıldığı bir çalışmada DEHB'nin erkeklerde kızlara oranla anlaml olarak daha fazla $(p<0.001)$ olduğu bildirilmiştir ${ }^{26}$. Sunulan çalışmada Öztop, Uyan ve ark.'nın ${ }^{5,26}$ çalışmalarına benzer şekilde DEHB ile ilişkili sorunların örneklem içerisindeki erkek öğrencilerde yüksek olduğu ve bu ilişkide istatistiksel farklılığın anlamlı olduğu belirlenmiştir ( $\mathrm{p}<0,05$; Tablo 2). DEHB madde/alkol kullanımı ve erişkinlikte antisosyal kişilik bozukluğu ile sonlanabileceği ve ergenlikte diğer psikiyatrik bozukluklarla görülme sıklığının yüksek olduğu göz önüne alınırsa; bu bulgu ergenlerin ruhsal sorun taramalarının

değerlendirilmesinin önemini ortaya koymaktadır.

Erişkin dönemde görülen psikiyatrik bozuklukların birçoğunun çocukluk döneminde başladığ 1 bildirilmekte ${ }^{27}$, psikiyatrik bozuklukların yaygınlığı yaşla arttığı görülmektedir. Psikiyatrik hastalıkların okul öncesi dönemde görülme oranı \%10,2 iken ergenlik öncesi dönemde \%13,2, ergenlik döneminde ise $\% 16,5$ olduğu belirtilmektedir ${ }^{28}$. Çalışmamızda örneklem içerisinden bulunan 18 yaşındaki öğrencilerin depresyon, anksiyete bozukluğu, travma sonrası stres bozukluğu ve alkol bağımlılığı ile ilişkili sorunlarının diğer yaş grubundakilere göre yüksek olduğu belirlenmiştir (Tablo 3). Yapılan epidemiyolojik çalışmalarda; ergenlik döneminde majör depresyon ve depresyon riskinin arttığ belirtilmekte, Yöntem Fidan tarafından yapılan çalışmada da anksiyete bozukluğu ve depresyon belirtilerinin özellikle erken ergenlik döneminde daha yüksek olduğu bildirilmektedir ${ }^{28}$. Kendine zarar verme davranışları tipik olarak ergenlik döneminde başlamakta, erişkin yaş grubuna göre ergenlik ve gençlikte daha fazla görülmektedir ${ }^{29}$. Ergenlerde gelişimsel özelliklere uygun değerlendirme ve ölçümler yapılarak değerlendirilen travma sonrası stres bozukluğu oranının yetişkin populasyonuna benzer olduğu bildirilmiştir ${ }^{30}$. Alkol ve madde kullanımının önemli oranda ergen yaş grubunda başladığı ve başlama yaş ortalamasının 15-19 yaş aralığında olduğu belirtilmiştir23,24. DEHB'nin çocukluk çağı ve adölesan dönemde en yaygın tanı alan ruhsal sorunların başında olduğu, ergen çalışmalarındaki prevalansın ergenlik öncesi yaş grubuna göre daha düşük bulunduğu belirtilmiştir 5,26. Sunulan çalışmada literatürle uyumlu olarak örneklem içerisinde yer alan öğrencilerin depresyon, anksiyete ve travma sonrası stres bozukluğu, alkol bağımlılığı ile ilişkili sorunlarının 18 yaşındakilerde 15, 16 ve 17 yaşındakilere, kendine zarar verme ve uyuşturucu bağımlılığı ile ilişkili sorunların 16 yaşındakilerde, 15,17 ve 18 yaşındakilere ve DEHB ile ilişkili sorunların da 17 yașındakilerde diğer yaş gruplarına göre yüksek çıkması özellikle ruhsal sorunların erken dönemde tanılanması için önemli bir kaynak olabileceğini ve gençlerden gelen verilerin can alıcı olduğunu göstermektedir.

Araştırmanın sınırlılıkları; araştırmanın sadece anket çalışmasından oluşması, örneklem grubu ile psikiyatrik görüşme yapılmaması, çalışmada kullanılan ölçeğin daha çok yasayla sorunu olan çocuklar için oluşturulan bir formun olması ve çalışmanın İl Milli Eğitim Müdürlüğü'ne bağlı liseye devam eden ve ulaşılabilen, araştırma kapsamına alınan 917 ergenden elde edilen verilerle kısıtlı olmasıdır. 
Tablo 3: Öğrencilerin depresyon, anksiyete bozukluğu, kendine zarar verme, psikoz, travma sonrası stres bozukluğu, alkol bağımlılığı ve dikkat eksikliği hiperaktivite bozukluğu ile ilişkili sorunlarının yaşa göre dağılımı

\begin{tabular}{|c|c|c|c|c|c|c|c|c|c|}
\hline \multirow{3}{*}{ Ruhsal Sorunlar } & \multicolumn{8}{|c|}{ Öğrencilerin Yaşları } & \multirow{3}{*}{$\mathbf{p}$} \\
\hline & \multicolumn{2}{|c|}{$\begin{array}{c}15 \text { yaş } \\
\mathrm{n}=540(\% 58,9)\end{array}$} & \multicolumn{2}{|c|}{$\begin{array}{c}16 \text { yas } \\
\mathrm{n}=104(\% 11,3)\end{array}$} & \multicolumn{2}{|c|}{$\begin{array}{c}17 \text { yaş } \\
\mathrm{n}=171(\% 18,6) \\
\end{array}$} & \multicolumn{2}{|c|}{$\begin{array}{c}18 \text { yaş } \\
n=102(\% 11,2)\end{array}$} & \\
\hline & Evet & Hayır & Evet & Hayır & Evet & Hayır & Evet & Hayır & \\
\hline Depresyon & $\begin{array}{c}374 \\
(\% 69,3)\end{array}$ & $\begin{array}{c}166 \\
(\% 30,7)\end{array}$ & $\begin{array}{c}88 \\
(\% 84,6)\end{array}$ & $\begin{array}{c}16 \\
(\% 15,4)\end{array}$ & $\begin{array}{c}151 \\
(\% 88,3)\end{array}$ & $\begin{array}{c}20 \\
(\% 11,7)\end{array}$ & $\begin{array}{c}94 \\
(\% 92,2)\end{array}$ & $\begin{array}{c}8 \\
(\% 7,8)\end{array}$ & $<0,001 * *$ \\
\hline Anksiyete bozukluğu & $\begin{array}{c}384 \\
(\% 71,1) \\
\end{array}$ & $\begin{array}{c}156 \\
(\% 28,9) \\
\end{array}$ & $\begin{array}{c}83 \\
(\% 79,8) \\
\end{array}$ & $\begin{array}{c}21 \\
(\% 20,2) \\
\end{array}$ & $\begin{array}{c}135 \\
(\% 78,9) \\
\end{array}$ & $\begin{array}{c}36 \\
(\% 21,1) \\
\end{array}$ & $\begin{array}{c}86 \\
(\% 84,3) \\
\end{array}$ & $\begin{array}{c}16 \\
(\% 15,7) \\
\end{array}$ & 0,008* \\
\hline Kendine zarar verme & $\begin{array}{c}152 \\
(\% 28,1) \\
\end{array}$ & $\begin{array}{c}388 \\
(\% 71,9) \\
\end{array}$ & $\begin{array}{c}40 \\
(\% 38,5) \\
\end{array}$ & $\begin{array}{c}64 \\
(\% 61,5) \\
\end{array}$ & $\begin{array}{c}57 \\
(\% 33,3) \\
\end{array}$ & $\begin{array}{c}114 \\
(\% 66,7) \\
\end{array}$ & $\begin{array}{c}39 \\
(\% 38,2) \\
\end{array}$ & $\begin{array}{c}63 \\
(\% 61,8) \\
\end{array}$ & 0,013* \\
\hline Psikoz & $\begin{array}{c}348 \\
(\% 64,4)\end{array}$ & $\begin{array}{c}192 \\
(\% 35,6)\end{array}$ & $\begin{array}{c}73 \\
(\% 70,2)\end{array}$ & $\begin{array}{c}31 \\
(\% 29,8)\end{array}$ & $\begin{array}{c}107 \\
(\% 62,6)\end{array}$ & $\begin{array}{c}64 \\
(\% 37,4)\end{array}$ & $\begin{array}{c}71 \\
(\% 69,6)\end{array}$ & $\begin{array}{c}31 \\
(\% 30,4)\end{array}$ & 0,300 \\
\hline $\begin{array}{l}\text { Travma sonrası stres } \\
\text { bozukluğu }\end{array}$ & $\begin{array}{c}160 \\
(\% 29,6)\end{array}$ & $\begin{array}{c}380 \\
(\% 70,4)\end{array}$ & $\begin{array}{c}42 \\
(\% 40,4)\end{array}$ & $\begin{array}{c}62 \\
(\% 59,6)\end{array}$ & $\begin{array}{c}58 \\
(\% 33,9)\end{array}$ & $\begin{array}{c}113 \\
(\% 66,1)\end{array}$ & $\begin{array}{c}49 \\
(\% 48,0)\end{array}$ & $\begin{array}{c}53 \\
(\% 52,0)\end{array}$ & 0,001* \\
\hline Alkol bağımlılığı & $\begin{array}{c}61 \\
(\% 11,3)\end{array}$ & $\begin{array}{c}479 \\
(\% 88,7)\end{array}$ & $\begin{array}{c}15 \\
(\% 14,4)\end{array}$ & $\begin{array}{c}89 \\
(\% 85,6)\end{array}$ & $\begin{array}{c}21 \\
(\% 12,3)\end{array}$ & $\begin{array}{c}150 \\
(\% 87,7)\end{array}$ & $\begin{array}{c}27 \\
(\% 26,5)\end{array}$ & $\begin{array}{c}75 \\
(\% 73,5)\end{array}$ & $0,001 *$ \\
\hline Uyuşturucu bağımlılığı & $\begin{array}{c}34 \\
(\% 6,3)\end{array}$ & $\begin{array}{c}506 \\
(\% 93,7)\end{array}$ & $\begin{array}{c}14 \\
(\% 13,5)\end{array}$ & $\begin{array}{c}90 \\
(\% 86,5)\end{array}$ & $\begin{array}{c}9 \\
(\% 5,3)\end{array}$ & $\begin{array}{c}162 \\
(\% 94,7)\end{array}$ & $\begin{array}{c}5 \\
(\% 4,9)\end{array}$ & $\begin{array}{c}97 \\
(\% 95,1)\end{array}$ & $0,033^{*}$ \\
\hline $\begin{array}{l}\text { Dikkat eksikliği } \\
\text { hiperaktivite bozukluğu }\end{array}$ & $\begin{array}{c}513 \\
(\% 95,0) \\
\end{array}$ & $\begin{array}{c}27 \\
(\% 5,0)\end{array}$ & $\begin{array}{c}102 \\
(\% 98,1)\end{array}$ & $\begin{array}{c}2 \\
(\% 1,9)\end{array}$ & $\begin{array}{c}170 \\
(\% 99,4)\end{array}$ & $\begin{array}{c}1 \\
(\% 0,6)\end{array}$ & $\begin{array}{c}100 \\
(\% 98)\end{array}$ & $\begin{array}{c}2 \\
(\% 2)\end{array}$ & $0,002 *$ \\
\hline
\end{tabular}

Ergenlerin depresyon, anksiyete bozukluğu, kendine zarar verme, psikoz, travma sonrası stres bozukluğu, alkol-uyuşturucu bağımlılığı ve DEHB ile ilişkili sorunları belirlemeye çalıştığımız çalışmamızda sonuç olarak örneklem grubumuzdaki $15-18$ yaş arasındaki ergenlerde ilk üç sırada DEHB, depresyon ve anksiyete bozukluğu ile ilişkili sorunların diğer ruhsal sorunlara göre daha yüksek olduğu belirlenmiştir. Bu doğrultuda; bu yaş grubunda ruhsal sorunların belirlenmesi için çocuk ergen ruh sağlığı alanında ulusal politikaların oluşturulması ve geliştirilmesi önerilmektedir. Yine psikososyal tarama aracinın kullanılması gereken en kritik zamanın ergenlik dönemi olduğu düşünülürse; bu taramaların belirli aralıklarla yapılması ve değerlendirilmelerin tekrarlanması önerilmektedir.

\section{Teşekkür}

Yazarların herhangi bir çıkar çatışması bulunmamaktadır. Tüm yazarlar verilerin toplanmasinda destek olan Yaser Mert'e teşekkür eder.
Çıkar Çatışması Beyanı: Yazarlar çıkar çatışması olmadığını bildirmişlerdir.

Finansal Destek: Bu çalışma her hangi bir fon tarafından desteklenmemiştir.

Declaration of Conflicting Interests: The authors declare that they have no conflict of interest.

Financial Disclosure: No financial support was received.

\section{KAYNAKLAR}

1. Bülbül SH, Güçlü M, Mısıroğlu ED. Kırıkkale il merkezi ilköğretim ve lise öğrencilerinde sigara ve alkol alışkanlıkları ve etkileyen faktörler. Türkiye Çocuk Hastalıkları Dergisi. 2013; 7:168-72.

2. Erbay E, Oğuz N, Yıldırım B, et al. Alkol ve madde bağımlılığı olan bireylerin başa çıkma tutumları. Turkish Jounal of Social Parlaz EA, Karademirci E. Ergenlik Dönemi: Fiziksel büyüme, psikolojik ve sosyal gelișim süreci. The Journal of Turkish Family Physician 2016; 3:10-6.

3. Kars V, Arslan N, Erik L. Lisen son sınıf öğrencilerinin meslek seçiminde karşılaștığı sorunlar ve bu sorunların anksiyete ve depresyonla ilişkisi. Dicle Med J. 2014; 41:187-90.

4. Tezel A, Özkan H, Parlak A. Bir okul hemşireliği uygulama programı: Erzurum il merkezinde bir 
ilköğretim okulu öğrencilerinin depresyon düzeyleri. Bozok Med J. 2012; 2:23-8.

5. Özbaran B, Köse S, Yılmaz E, et al. Çocuk ve ergen psikiyatrisi uygulamasında yataklı servis deneyimi ve yatışın iyileşmeye katkısının değerlendirilmesi. Anatolian J Psychiatry. 2016; 17: 120-6.

6. Öztop DB. Adolesanda ruhsal sorunlar. Turkish Journal of Family Practice. 2012; 16:14-8.

7. Weitzman C, Wegner L, Blum NJ. Promoting optimal development: Screening for behavioral and emotional problems. Pediatrics 2015; 135:384-95.

8. Dursun OB, Güvenir T, Özbek A. Çocuk ergen ruh sağlığında epidemiyolojik çalışmalar: yöntemsel bir bakış. Current Approaches in Psychiatry. 2010; 2:40116.

9. Ögel K, Karadayı G, Şenyuva G, et al. Yasayla ihtilafa düşen ergenlerin risk ve ihtiyaçlarının değerlendirilmesi: Araştırma ve değerlendirme formunun (ARDEF) geliştirilmesi ve standardizasyonu. Anatolian J Psychiatry. 2011; 12:143-50.

10. Ögel K, Karadayı G, Şenyuva G, et al. Ergenler için ruhsal sorunlar tarama ölçeği'nin geçerlilik ve güvenilirlik çalışması. Düşünen Adam The Journal of Psychiatry and Neurological Science. 2012; 25:8-16.

11. Barry MM, Clarke AM, Jenkins R, et al. A systematic review of the effectiveness of mental health promotion interventions for young people in low and middle income countries. BMC Public Health. 2013; 13:1-19.

12. Lindemann C, Langner I, Kraut A, et al. Age-specific prevalence, incidence of new diagnoses, and drug treatment of attention-deficit/hyperactivity disorder in Germany. J Child Adol Psychop. 2012; 22:307-14.

13. Schulenberg J, Schoon I. The transition to adulthood across time and space: Overview of special section. LongitLife Course Stud. 2012; 3:164-72.

14. Durukan İ, Karaman D, Kara K. Çocuk ve ergen psikiyatrisi polikliniğine başvuran hastalarda tanı dağılımı. Düşünen Adam The Journal of Psychiatry and Neurological Science. 2011; 24:113-20.

15. Akdemir D, Zeki A, Ünal DY. Kendine zarar verme davranışı olan ergenlerde psikiyatrik belirtiler, kimlik karmaşası ve benlik saygısı. Anatolian J Psychiatry. 2013; 14:69-76.

16. Haspolat YK, Karabel M, Karabel D, et al. Ergen polikliniğine başvuran olguların sosyodemografik özelliklerinin değerlendirilmesi. Dicle Med J. 2016; 43:62-6.

17. Saçarçelik G, Türkcan A, Güveli H. İkinci basamak ergen ve genç erişkin psikiyatri polikliniğine başvuranhastalarda kasıtlı kendine zarar verme davranışının yaygınlığı ve sosyodemografik özelliklerle iliş̧kisi. Düşünen Adam The Journal of Psychiatry and Neurological Science. 2011; 24:253-64.

18. Kocal Y, Karakuş G, Sert D. Şizofreni: Etyoloji, klinik özellikler ve tedavi. Archives Medical Review Journal. 2017; 26:251-67.

19. Binbay $T$, Ulaş $H$, Elbi $H$. Türkiye'de psikoz epidemiyolojisi: Yaygınlık tahminleri ve başvuru oranları üzerine sistematik bir gözden geçirme. Turkish Journal of Psychiatry. 2011; 22: 40-52.

20. Diagnostic and Statistical Manual of Mental Disorders, Fifth edition. Arlington, VA., American Psychiatric Association; 2013.

21. Binbay T, Direk N, Aker T. Türkiye'de psikiyatrik epidemiyoloji:Yakın zamanlı araştırmalarda temel bulgular ve gelecek için öneriler. Turkish Journal of Psychiatry. 2014; 25: 264-81.

22. Bolu A, Erdem M, Öznur T. Travma sonrası stres bozukluğu. Anatol J Clin Investig. 2014; 8: 98-104. Research. 2016; 20:597-609.

23. Softa HK, Karaahmetoğlu GU, Ergun S. Lise öğrencilerinde madde kullanımı ve ilişkili faktörlerin incelenmesi (Kastamonu ili örneği). Journal of Dependence. 2015; 16:167-74.

24. Köse EÖ, Gül Ş, Keskin B. Ortaöğretim öğrencilerinin madde bağımlılı̆̆ ile ilgili farkındalık ve bilgi düzeylerinin incelenmesi. Journal of Dependence. 2017; 18:8-15.

25. Uyan Z, Peker GC, Tekiner S, et al. Ergenlerde dikkat eksikliği hiperaktivite bozukluğu sıklığının araștırılması. Konuralp Medical Journal. 2014; 6:21-6.

26. Demirkaya SK, Aksu H, Yılmaz N, et al. Bir üniversite hastanesi çocuk ve ergen psikiyatrisi polikliniğine başvuran olguların tanıları ve sosyodemografik özellikler. Meandros Med Dent J. 2015; 16:4-8.

27. Yöntem Fidan T. Bir çocuk-ergen ruh sağlığı ve hastalıkları polikliniğine başvuran çocuk ve ergenlerin ruhsal belirtileri ve risk faktörlerinin değerlendirilmesi. Konuralp Medical Journal. 2011; 3: 1-8.

28. Timson D, Priest H, Clark-Carter D. Adolescents who self-harm: Professional staff knowledge, attitudes and training needs. J Adolesc. 2012; 35:1307-14.

29. Calitz FJW, de Jongh NJ, Horn A, et al. Children and adolescents treated for post-traumatic stress disorder at the Free State Psychiatric Complex. S Afr J Psych. 2014;20: 15-20. 